\title{
Deviant Online Behavior in Adolescent And Youth Circles: in Search of a Risk Assessment Model
}

\author{
Nikolay V. Dvoryanchikov", Inna B. Bovina1, Varvara V. Delibalt1, Elena G. Dozortseva², Natalya V. Bogdanovich', Olga V. \\ Rubtsova ${ }^{1}$ \\ ${ }^{1}$ Moscow State University of Psychology and Education, Moscow, Russian Federation, e-mail: dvoryanchikovnv@mgppu.ru; \\ innabovina@yandex.ru; delibaltvv@mgppu.ru; bogdanovichnv@mgppu.ru; rubcovaov@mgppu.ru \\ ${ }^{2}$ Moscow State University of Psychology and Education, Serbsky National Medical Research Centre for Psychiatry and \\ Narcology, Moscow, Russian Federation, e-mail: edozortseva@mail.ru
}

\begin{abstract}
The authors made an attempt to describe the problem of developing the concept of risk assessment of deviant online behavior of minors and young adults in social networks. The article looks into the psychological consequences of banalizing of the internet, analysis possibilities for offline and online behavior. Approaches for risk factors assessment of deviant behavior in real life are described: the qualitative (clinical), statistical (actuarial) and structured. The article systemizes the studies of risk factors, vulnerability, and deviant patterns in the context of phenomena such as aggressive, asocial, autoaggressive, self-mutilating, suicidal, risk-taking and victim online behavior. Approaches and models of online deviant behavior are discussed; an attempt is made to build a structured model of risk assessment of deviant patterns of online behavior in the context of the cultural historical concept. On the basis of theoretical analysis, a hypothetical set of group, interindividual and intraindividual constructs is formulated, the combination of online and offline risk factors produces a model for risk assessment of deviant behavior. The article is written as part of the research project "Developing the profiling model of online behavior of minors and young adults in social networks" which was initiated by the Moscow State University of Psychology and Education.
\end{abstract}

Keywords: deviant online behavior, minors, young adults, social networks, risk factors, vulnerability, resources, risk assessment.

\section{Introduction}

In the modern world technologies are becoming an important part of people's life, transforming it in such a way that people tend to see themselves as important participants in numerous global processes. The technology enables an individual to become a witness of events (albeit virtually) occurring many miles away. Now, like an editor of a media one can influence how important a particular piece of news is among other news, engage in debating topics of interest with absolute strangers, make one's protest, block those participants in the discussion whom he/she doesn't really like, comment on events of all sorts etc (Tikhonova et al., 2017). It's hardly possible to call in question the point that the internet has given people powers they didn't have before (Tkhostov, 2018).

According to the survey results published by Hootsuite as of 2019 (Global digital report, 2019), $57 \%$ of the world population (4.388 bln people) are internet users, $45 \%$ of the population ( $3.5 \mathrm{bln}$ ) use social networks. The corresponding numbers for the Russian Federation are the following: $76 \%$ of the population are internet users and slightly less people - $49 \%$ - are social networks users. On average the Russian internet users spend online 6 hours and 29 minutes every day (which is 1.55 times less than those in Philippines do, but 1.73 times more than in Japan). According to the same source, social networks are used for 2 hrs 16 mins. (Global digital report, 2019). A cursory glance can show that no matter where users of the World Wide Web are (at scientific conferences, important meetings, attending classes in school or in universities, sitting in cafes, walking along streets, driving their cars etc.), they always find themselves faithfully following latest developments, reading the news, using social networks, playing online games, watching football matches or films.

The estimates obtained through the survey are debatable though, as internet users can hardly be

"Corresponding author: dvoryanchikovnv@mgppu.ru 
accurate in their appraisals for a number of reasons (getting involved in online activities which distorts perception of time, or self-justification, because it can be revealed from self-observation that everyone is spending increasingly more time online - in the public transport, during one's education classes, at home etc, i.e. users underrate their appraisals of the time they spend online). If we turn to the criteria of internet addiction or problem internet usage suggested by K. Young (similarly to the signs of pathological gambling), then presence of the following 5 signs indicates addictive online behavior: 1) preoccupation with the internet; 2) the need to prolong one's online session for self-gratification; 3) recurrent efforts to spend less time online; 4) irritability; 5) depression; 6) mood swings when internet usage is limited; 7) online sessions take longer than expected; 8 ) work and relations become threatened by the internet usage; 9) misleading others about one's time online; 10) using the internet to feel better (Young,1998). It is obvious that online time appraisals aren't accurate.

Thus, the general tendency is as follows: the number of people who use the internet and social networks is in steady rise, adolescents and young people are the most active population group. Besides, the age of starting internet usage is decreasing. And so is the age when people start using the internet independently and decide for themselves what content to consume. Because of technological progress, this media source has become personalized and gone mobile (Livingstone et al., 2011). According to the most recent studies made in European countries (including Russia), it seems possible to state that over the decade there's been a significant growth in the number of smartphone users, and that the amount of time which happy internet users spend online has risen, having doubled in a number of countries (Smahel et al., 2020). And these are adolescent circles.

\section{Psychological consequences of banalizing the internet}

Researchers' attention is largely attracted to looking at what happens to an individual while online, what psychological consequences of using modern technology (including the internet) there are. The consequences do exist, as a large part of one's day-to-day life is spent online, as far as it can be judged from the statistical data (Internet in Russia, 2018; Global digital report, 2019).

According to Tkhostov A.Sh., it should be possible to indicate a number of consequences of misusing technology, both specific and non-specific. In the former case the base defect is effort deficit as well as voluntary regulation deficit. Secondary disorders are linked to difficulties with initiating and planning an activity, impaired control, and infantilization. In the latter case the basic defect is the isolation of higher mental functions and disruption in their hierarchical structure. In this case the secondary impairments are associated with "clipped mindset", barriers blurring, problems with undertaking obligations and accepting responsibilities, subordination as well as diffused identity (Tkhostov, 2018). Due to insufficient space for discussing this problem here, let's ask ourselves though, what misuse is. 6.5 hours of time a day which is devoted (on average) voluntarily to the internet - is it a sign of this misuse?

The exponential growth of social networks usage (Global digital report, 2019), has undoubtedly had an effect on the interpersonal communication specifics, for it has largely moved from the real world to the virtual world (Lowry et al., 2016). As A. Kende maintains, "Social media (and the attendant technologies) pose probably the largest upheaval to the way in which people interact and engage with each other since the time of William James" (Kende et al., 2015, p. 277).

So, the consequences of the breakthrough emphasized by A. Kende include a deep transformation of the communication process itself, of the power relations which are conjugated with it, in particular those linked with widening the rights which participants may have in communication (Marzouki, 2016), the changes touched the communication norms as well. What belongs to other qualitative changes of communication process as compared with the real world situations is its simplification. Participants in communication now have significant freedom for staying anonymous (with all the ensuing psychological consequences and interaction specifics given by the anonymity). What we relate to qualitative differences of the communication process occurring via the internet is the ability to modify or construct one's identity, interrupt or altogether stop one's communication at every moment (Emelin, V. A. and Tkhostov, A., 2015, 2016).

Using new technology, in particular the internet, alters the actor himself/herself and also affects his/ her communication with others, changing the nature of the process. And now the question is: do the things mentioned above suggest that with the advent of the internet and its widespread use the communications in real life, too, undergo changes or maybe the changes primarily occur in online communications rather than in the real world, without affecting the latter. If we take Tkhostov's ideas, then it follows that in the so called digital era it becomes possible to speak about the changes happening to an individual and to the way he/she thinks, feels and behaves with all the ensuing consequences. 


\section{Online and offline behavior: some analysis possibilities}

A number of researchers ask themselves how behavior in the real world relates to that in the internet. It seems possible to indicate a significant number of empirical facts, obtained within the framework of differing theoretical models (for example, Bandura, 1977; Joinson, 2007; Kende et al., 2015; Moor and Anderson J. A, 2019). There are empirically obtained reasons to believe that people are better at expressing their true selves while online than in real life (Kende et al., 2015). Experimental results suggest that the internet and social networks in particular are a means of mobilizing people to participate in collective acts (Kende et al., 2015; Shumann and Klein, 2015). At the same time other studies indicate the emergence of 'slacktivism' (the so-called 'couch activism'), which is a less costly form of activity (draw up or sign an online petition, share some information in the Net) than real actions (Shumann and Klein, 2015). Let's outline here some possibilities for studying the problem of relationship between online and offline, in particular, related to deviant, anti-normative behavior on the internet and its correlation in real life.

The phenomenon, whose consideration is appropriate in connection with studying the aforementioned problem of relation between online behavior and behavior in real life is disinhibition online.

A. Joinson, basing on the work of F. Zimbardo, suggested defining the phenomenon of disinhibition in the following way: "if inhibition is when behavior is constrained or restrained through self-awareness, anxiety about social situations, worries about public evaluation and so on, then disinhibition can be characterized by an absence or reversal of these same factors ... disinhibition on the Internet ... is seen as any behavior that is characterized by an apparent reduction in concerns for self-presentation and the judgement of others" (Joinson, 2007, p.63).

From the point of view of $\mathrm{J}$. Suller the essence of this phenomenon is that individuals behave differently in online communications (say and do things they wouldn't allow themselves in real communications) (Suler, 2004). While not something pathological, disinhibition can be implemented in two independent forms (ibid): in one case (benign disinhibition) the individual shares very private information, discloses his/her secrets, fears, doesn't conceal their emotions, tries to help another person (but is excessively supportive). In the opposite case (toxic disinhibition) the individual is rude to another person, expresses undue criticism or even threats, visits websites whose content has violence, brutal actions, aggression. As Suller writes, it is unlikely that that individual would visit this territory in real life. If the first online disinhibition form can be linked to personal growth and development, then it is interesting to know what consequences of the second disinhibition form might be. According to Suller (ibid), emergence of disinhibition has nothing to do with pathological processes. All that matters is that the cyberspace is conducive to lowering the barriers that control one's behavior in real communication. Suller suggests a six-factor model of online disinhibition effect: dissociative anonymity, invisibility, asynchronicity, solipsistic introjection, dissociative imagination, and minimization of authority (ibid).

On the one hand, among other explanatory mechanisms, applicable to studying online disinhibition, there is a phenomenon of deindividuation, which was originally described by Lebon in his works on mob psychology as early as 1895 (Lebon, 2011). The mechanisms of deindividuation were studied experimentally by Festinger and his colleagues (Festinger, Pepitone and Newcomb,1963) almost half a century later. The transformation that happens to an individual in a crowd, does not emerge exclusively in a large natural group, it happens every time the individual finds himself/herself in a group. According to L. Festinger: "There occurs sometimes in groups a state of affairs in which the individuals act as if they were "submerged in the group." Such a state of affairs may be described as one of de-individuation; that is, individuals are not seen or paid attention to as individuals....under conditions where the member is not individuated in the group, there is likely to occur for the member a reduction of inner restraints against doing various things" (ibid, p.382). It is obvious that a person behaves differently in the deindividuation state than he/she does outside this state and it is also clear that the analysis of one's behavior online is hardly applicable to predicting that in the real life.

Another analysis direction, diametrically opposed to the one mentioned above, originates in the dark triad (or tetrad) logic. It has intraindividual constructs of psychopathy, machiavellianism and narcissism (the construct added to make a tetrad is sadism). Numerous studies suggest that people with these traits are predisposed to asocial, non-standard, transgressive behavior and violation of social norms (Buckels, Trapnell and Paulhus, 2014; Mededovic and Petrovic, 2015; Moor and Anderson, 2019). The appeals to "the dark triad" undoubtedly seem valid. On the basis of the systematic analysis of 26 studies Moore and Anderson arrive at the conclusion that the traits contained in "the dark triad" are related to trolling, cyberagression, cyberidleness, sending unwanted images, cyberbullying, misuse of social networks and the internet, problem online gambling, etc. The studies reviewed suggest that psychopathy is the trait 
that is most pertinent to this behavior. Machiavellism and sadism are somehow related to it, too, but to a lesser degree. Finally, narcissism is the least connected with asocial behavior on the internet (Moor and Anderson, 2019).

There are empirical indicators, making it possible to identify the possessors of such personality traits (Panicheva, Ledovaya and Bogolyubova, 2016). In other words, it opens an opportunity to identify individuals with the dark tetrad on the basis of lexico-semantic indicators in texts, posted in social networks, and furthermore - make projections into the future regarding violation of norms both on the internet (such as bullying, trolling) and in real life. However, this combination of intraindividual constructs isn't unique - numerous publications contain considerable number of studies, appealing to various personality dispositions that are linked to deviant behavior (Martínez-Ferrer, Moreno and Musitu, 2018).

\section{Deviant behavior: risk, vulnerability, protective factors and approaches for assessing it offline}

Traditionally in the domain of deviantology and legal psychology what is understood as deviant behavior is persistent, recurring behavior which violates social norms, is not in line with the conventional values and rules, is negatively judged by other people, leads to the individual's maladaptation, is harmful to both the person and the society. In different classifications certain parameters serve as the criteria for deviant behavior. They are: the violated norm type, the psychological aims for the behavior and its motivation, implications and damage done, as well as individual and stylistic parameters of the behavior (Zmanovskaya, 2003; Delibalt et al., 2017).

In the context of behavioral problems, related to deviant behavior, asocial manifestations or behavioral disorders these concepts are used: "risk", "vulnerability", "resources for development". Combined together, they can either aggravate or ameliorate various difficulties. Risk is understood as any condition or circumstance that increases the likelihood of formation of problem or deviant behavior (Wenar and Kerig, 2007). At the same time, it is important to note the impossibility of making a comprehensive risk factors list because the cultural-historical context always changes. Risk can condition the formation and development of behavioral difficulties, but it just points to the probability of problems for the children who are exposed to it. According to a number of studies, it is possible to single out the most prevalent risk factors in an individual's childhood which predispose him/her to delinquent behavior in adolescence. For instance, learning impairments, learning disability, severe behavioral problems (e.g. acts of arson or cruelty to animals), school problems, family dysfunction, delinquent peers in one's environment etc.

However, even information about the risks isn't enough to prognosticate the individual's behavior. It is also necessary to find the so-called vulnerabilities, i.e. the factors which increase his/her reaction to risk (Wenar and Kerig, 2007). A vulnerability only increases the chance of emerging of behavioral problems in those children who are susceptible to it; it manifests itself as an interactive effect. Among the factors pertaining to vulnerabilities are (Rutter, 1985) quick temper, underdeveloped ability for planning, lack of positive school experience, lack of loving care, poor social skills etc.

In addition to it, it is also necessary to take into account the so-called protective factors or development resources, i.e. the factors which increase the individual's stability against adverse factors (Wenar and Kerig, 2007). It is important, because not all children, who are at risk, develop behavioral disorders. At the same time, the full spectrum of protective factors is also lacking, and so is the risk factors list. Various studies show that the factors belonging to the development resources can be high intelligence level, emotional maturity, wide circle of interests, good progress in one's studies, communications with prosocially behaved peers, support from a prosocial adult, the ability to ask for help, love and care in one's family and others (Rutter, 1985).

Analyzing factors of risk, vulnerability and resources plays a special role in developing assistance and prevention programs, in particular, this problem is acute in the domain of preventing of recurrence of socially dangerous behavior. Three approaches can be marked out to assess the risk of deviant and unlawful behavior: qualitative (clinical), quantitative and structured (McMurran, 1996; Dozortseva et al., 2011).

The qualitative (clinical) approach was used in forensic psychiatry for resolving issues with illegal behavior prediction. The objective was to provide a list of criteria whose assessment would be useful in finding the probability of committing various criminal acts by patients. The factors assessment was carried out through qualitative analysis of the clinical presentation, the course of the mental disorder and its prognosis. This approach implies an in-depth, comprehensive analysis on the basis of the experts' knowledge and experience, but is more focused on individual risk assessment. The approach isn't perfect, as the assessments and diagnostics are inherently subjective, labor- and time-consuming in their procedure. Besides, the resolutions passed tend to indicate high risk of illegal behavior, violence and 
aggression. To address these problems a number of steps were taken to standardize the assessment criteria; certain mathematical algorithms and procedures were suggested to evaluate the efficiency of the resolutions. (Makushkin et al., 2009; Dozortseva et al., 2011; Monahan and Steadman, 1996; Dolan and Doyle, 2000).

The second approach to risk assessment is statistical (quantitative or actuarial). It appeared as an alternative to the qualitative one and is built upon assessment and analysis of risk factors of unlawful behavior in various gender and age groups, which are statistically obtained on the basis of formalized procedures and scales. In doing so, various demographic data are used, for example, the age of debut of the problem behavior and delinquency, the development history of aggressive behavior and other social attributes, obtained from the statistical analysis. The tools developed within this approach contain a fairly limited number of assessment parameters (these are relatively stable) as well as clear procedures of quantitative assessment. Thus, the limitations of this approach lie in the fact that individual psychological specifics of a person are not taken into account. It therefore follows that these tools are of limited prognostic validity (Monahan and Steadman, 1996; Dolan and Doyle, 2000; Makushkin et al., 2009, Dozortseva E. G. et al., 2011).

The third approach is an attempt to overcome the limitations of the two approaches mentioned above and is built upon the idea of structured assessment of unlawful behavior risk. Such assessment is quite flexible and combines both qualitative and quantitative approaches. The tools, developed as part of this approach, make it possible to assess the risk over time and to take into consideration the so-called "historical risk factors". The assessment is built upon comparison of various facts about the case, which makes it possible to structure quantitative and qualitative risk factors of the past, of the current situation and also find protective factors, i.e. resources. It provides an opportunity to make a probabilistic prediction about the behavior. At the same time, to improve assessment precision, mandatory requirements are imposed: the information assessed must be recorded in different sources, the assessment criteria must be clear and unambiguous, the assessment must be limited to a certain period of time and the assessment inventory should be intended for certain categories of offence (Wallinius M., 2012; Dozortseva E. G. et al., 2011). Among the tools implementing this approach Youth Risk/Needs Assessment (RNA) Tools should be mentioned (Hoge and Andrews, 2002; Hoge, Andrews and Leschied, 2002; etc.). The principles of this method were also applied in the tool "Risk and Possibilities" that is fairly often used in Russia for prognostic risk assessment of repeated illegal behavior and for constructing an individualized work program for a particular minor (Bulgakova et al., 2009).

\section{Online-behavior: the study of factors of risk, vulnerability and deviant patterns}

Using of approaches and tools for risk factors assessment of deviant and unlawful behavior relies more on the data obtained from minors' offline life. However, as it was pointed out earlier, nowadays minors and young adults make extensive use of the internet and the most popular with them are different social networks. Both offline communications and those in social networks may hold potential risks for users' psychological safety. 4 types of such risks are distinguished by Soldatova G.U. et al., (2013): 1) content-related risks, caused by viewing information which evokes stress; 2 ) communication-related risks, involving chances of user's confrontation with various unwanted communications (different forms of cyberbullying, sexual harassment, etc); 3) technology-related risks existing due to the user's difficulties in interacting with social networks websites/apps, as well as hacking into the user's cloud-based accounts; 4) consumer-related risks, including internet scam (fake online shops or charities, phishing etc).

In their study of controlling content-related risks which students have in social networks Zhdanova S. Yu. and Doronina V. F. (2019) attempted to single out the content-related risks categories which social networks users may encounter. Using content analysis, the authors analyzed the answers that the respondents gave to the questions from a questionnaire and singled out 8 risk categories (false information; information about violence and injuring oneself and others; sexual content; promotion of illicit substances; propaganda of ideas and social movements; information that changes one's mental state; information transgressing moral and ethical standards; advertising) and their formal characteristics. The results of the study indicate that the most prominent content occurring in social networks is one which violates moral and ethical standards, which is then followed by information influencing one's mental state (like shocking content), and also information related to violence, aggression and false information.

However, the question is: if it is possible to speak about any norms on the internet, how these norms get manifested, how they correlate with the norms in the offline reality, what the way of their interiorizing is and also how these norms influence online activity and online behavior.

Emelin, V. A., and Tkhostov, A. (2013) point out that the functions of the Internet can be put into 
two related but independent enough domains: informational and communicative. Translating this into the terms of online behavior, one can suggest the existence of its two forms (online work with information and communications), with which one can associate various kinds of it, encompassing more special cases of manifestation of online activity.

Researchers' attention is in particular drawn to one's online search behavior, which is able to reflect one's current needs, as well as cognitive styles (Madle et al. 2009). One should mention the involvement into online behavior (probably into its specific manifestations and not generally) which is influenced by the user's psychological and social characteristics, his/her skills and expectations (Short C. E. et al., 2015).

Researchers often view online behavior as a form of social behavior (Brodovskaya, 2016; Pelaprat, 2012). Attempts are made to single out its strategies. In the first place, what is taken into consideration, especially in the initial stages of research, is how intense one's online behavior is (how much time is spent online) and later on the content of one's online behavior (communication, search for information, services in various contexts) is considered (Brodovskaya, 2016; Java et al., 2007).

There are culturally conditioned peculiarities in online behavior of different people which, in turn, determine their attitudes, values, ideas and behavioral patterns. Online activity can also influence one's cognitive styles and behavior in reality (Attrill, 2016). Among other things, the studies indicate the link between individual-psychological personality traits and one's online behavior specifics (Rubtsova, Panfilova and Smirnova, 2018; Whitty et al., 2018), as well as the possibility of one's online behavior being influenced by different identities at various moments, depending on which one comes to the fore in certain situations (Helsper, 2014).

Online behavior happens in reality and, mediated by technology, is displayed in the virtual space. Therefore, despite all the layers of virtual space, that refract mental processes, online behavior must contain the element of psychical functioning, typical for real life activity. At that, there must be mechanisms, providing changes to online behavior as compared to the real one. It can be assumed, that the forms of online behavior ("dealing with information" and "communication") are closely linked. Oftentimes one form may come as leading and the other one as auxiliary. Thus, online behavior can be defined as a form of social behavior, occurring in the virtual space and to a certain extent reflecting the user's individualpsychological and socio-psychological features.

Internet space and social networks are not only digital reality, but also act as the new social community. At present, the studies of mechanisms of cyber- or digital socializing are of certain relevance. (Chitosca, 2006; Pleshakov, 2012; Luchinkina, 2015; Delaney and Madigan, 2017; Soldatova, 2018; Aysina and Nesterova, 2019). This process is seen as the user's integration with electronic socio-cultural environment and is connected with his/her familiarizing with the culture values, norms and rules of online communications. According to Soldatova G.U. (2018), in the virtual space the individual obtains some social experience, which is then reproduced in the mixed reality of online and offline. That leads to formation of one's digital personality as part of his/her real personality.

Aysina P. M. and Nesterova A. A. (2019) point out that cyberspace generates and suggests its own rules and norms of communication, absent in the offline reality. In the authors' opinion, the traditional socializing and cyber-socializing can either mutually complement or disagree with each other. At that, it is suggested to single out two types of cyber-socializing: a positive and a negative one. The positive cybersocializing involves gaining helpful experience online, using it as development resource for the offline reality, it also involves safe exploration of the cyberspace. The negative cyber-socializing manifests as the user's intense online activity combined with "poor capacity for self-regulation while using online resources along with deviant patterns in one's online communications and/or high vulnerability to aggressive online interventions" (Aysina and Nesterova, 2019, p.49). The authors also mark out three levels of cybersocializing - high, medium and low. However, what remains debatable and requiring empirical testing is the question of how these types of cyber-socializing are related to one's social functioning in real life and how online and offline deviant patterns correlate.

The researchers' attention in the context of studying deviant patterns of online behavior in social networks and internet space encompasses phenomena such as aggressive, asocial, auto-aggressive, self-mutilating, suicidal, risk-taking and victim online behavior. At the same time, various strategies and research designs are used. For instance, what is analyzed is the content of online communities in different social networks and services such as VKontakte, Facebook, Instagram, YouTube and others. The researchers study the links between the parameters of the internet and social networks usage (frequency, popularity, audiences' gender structure etc.) and the occurrence of certain behavioral problems. They correlate the psychological make-up of internet users' and their tendency to various kinds of deviant behavior. Attempts are made to find relationships between the psychological make-up of the subjects and the publicly available contents of their online accounts (with their consent). 
Thus, the research work by Vaske E. V. and Goryunova O. I. (2018) gives the results of a psychological and legal analysis of destructive online manifestations on the example of 228 internet communities created in VKontakte and Instagram. The total audience is more than $1.5 \mathrm{mln}$ users aged 12-25. The authors analyze the content specifics and describe the typology of the online groups (the communities advocating delinquent attitudes, near-extremist symbols, scenes of violence and atrocities, suicidal content etc.). The study showed that the activities of internet groups administrators aimed to develop stereotypes of destructive behavior of various extent and orientation in their visitors without critical understanding on the part of the visitors.

According to the data obtained by Soldatova G. U., Chigarkova S. V. and Lvova E. N. (2017), adolescents of 12-17 often face aggressive communications on the internet. However, the Pew Research Center data suggest that not only minors, but also adults faced various types of harassment or bullying (40\% of internet users), $73 \%$ of the respondents witnessed it (Duggan, 2014). In addition to age, gender is an important factor of cyber-bullying, too: boys act as aggressors more often, but they tend to undergo online harassment more often as well. Girls are more at risk to be victimized by cyberbullying (Kiriukhina, 2019).

The main peculiarities of online harassment are anonymity, regularity, lots of witnesses (both known and unknown), lack of feedback and uninhibition (Khlomov, Davydov and Bochaver, 2019).

The predominant types of aggression are flaming, trolling, hating, aggressive messaging, "happy slapping", sexting, cyberbullying and others (Bocij and McFarlane, 2003; Spears et al., 2009; Soldatova, Chigarkova and Lvova, 2017). Cyber-humiliation can also involve online taunting or social online cruelty via email, instant messaging, chats, personal websites, gaming websites, pager messaging and digital messages or images sent through cellular phones (Kowalski, Limber and Agatston, 2012).

It is noted that the key motives of cyberbullies are domination and amusement, whereas impunity, anonymity and some other attributes of online space simplify aggressive communications (Soldatova, Chigarkova and Lvova, 2017). Among other motives are communication problems, participation need (Pronk and Zimmer-Gembeck, 2010), dominance need, (Pellegrini and Bartini, 2001) and others. The major problem is the scarcity of studies in the field of motivational sphere of offline and online harassment. However, some authors state that cyberbullies have similar motives as conventional bullies do (Sanders, Smith, and Cillessen, 2009). In the domain of motivational sphere of cyberbullying there are studies highlighting the motive of revenge (22.5\%) (Hinduja and Patchin, 2014). But, as we see it, these studies don't emphasize if this revenge is directed against a particular person (previously harassed in the conventional, offline way) or if it is aimed at some other person. Among cyberbullying motives can be "they deserve it" attitude towards those with bad reputation, pressure upon children of the same age in the context of their urge to conform with their reference group, "boredom and looking for fun" as a way to fill the gap in one's life in the absence of hobbies or interests (Kiriukhina, 2019).

Some authors emphasize that real world and online harassment are somehow related. The majority of cyberbullies experienced cyber-victimization, and nearly half of them experienced harassment in real life (Ybarra and Mitchell, 2004).

There are studies showing that girls act as online bullies more often than boys do (Owens, Shute and Slee, 2000). This agrees with the studies, stating that girls are more likely to resort to indirect forms of aggression than to direct ones. Cyberbullying can be called an indirect form of harassment, since one's ideas can be expressed without any personal contact. Thus, there is no limit to things that can be written (Keith and Martin, 2005).

Some studies suggested looking into the personality of the cyberbully and his/her victim. For example, the work conducted by Australian researchers and aimed to find differences in victims and non-victims of cyberbullying in terms of attachment, locus of control, self-esteem and copying strategies, produced the following results: there were slight differences in all respects except self-esteem. The selfesteem in the subjects who faced cyberbullying only once was higher than in those who have never confronted online harassment or have been the victim of cyberbullying multiple times (Muller, Skues and Wise, 2017).

John, et al. (2018) point out that children and youth under 25 , who were the victims of cyberbullying are susceptible to double risk of self-mutilating and suicidal behavior and it should be taken into account when developing a preventive program.

Semenov A., Veijalainen J. and Kyppö J. (2010) show that oftentimes the adolescents who committed school shooting have personal pages in social networks where they leave traces of their internet activities and some markers which make it possible to assess their intentions to carry out attacks on schools. According to the study conducted by Dozortseva E. G., Oshevskiy D. S. and Syrokvashina K. V. (2020) on the basis of criminal cases analysis during psychical and psychiatric examination, the 
adolescents who committed attacks on schools were outcasts and isolated in their classes, their identities indicate orientation to the role models of the minors who committed the attack on the "Columbine" school in USA. Data are obtained showing that the shooters had suffered from bullying in their schools, and, at the same time, their internet activities and the social networks communities which they visited served as factors of influence and emotional support. Also, these adolescents are distinguished by aggressive and auto-aggressive behavior shaped long before their shooting, some of them have mental health problems.

Polskaya N. A. and Yakubovskaya D. K. (2019) presented a publications review on self-mutilating behavior in social networks. The authors give generalized data from various studies indicating that 38$50 \%$ of adolescents and young people demonstrate online self-mutilating behavior. Referring to the study conducted by Moreno, Ton, Selkie, et al. (2016), they note that during 2014 and 2015 the English-speaking segment of Instagram experienced growth from $1.7 \mathrm{mln}$ to $2.4 \mathrm{mln}$ in users' postings of self-mutilation. The researchers marked out content categories of self-mutilative behavior in social networks such as hashtags, images and comments. The study shows that online communications can have positive effect on users' condition (e.g. one can have one's spirits raised, get help and support etc), but they can also act as risk factors strengthening the users' tendency towards self-mutilation (or interest to it), increasing morbid emotional reactions, unsafe risk-taking behavior and imitation. It is noted that the adolescents who are susceptible to self-mutilation can be vulnerable in social networks, which increases the risk of becoming a victim of cyberbullying. The study indicates the necessity of developing preventive programs and assistive content.

Sokolova M. V. and Dozortseva E. G. (2019) researched the inclination to auto-aggressive behavior in adolescents and the information they consume online. The pilot study revealed correlations between auto-destructive, suicidal tendencies and the frequency of consuming unwanted content, between aggression and anxiety and consuming destructive information as well as correlations between different tendencies toward deviant behavior and visiting social network communities having inappropriate content.

The problem of online suicidal behavior is considered in the study conducted by Luchinkina, A. I. (2015). It was shown that the suicidal virtual personality is based on the real one and that the manifestations of the former are influenced by one's: motives for one's online presence; technical savviness; selection of personal mythology (e.g. associating suicide to bravery, love to misfortune, one's quarrels to death, and to top it all, the main message is one's uselessness; one's death is seen as a means to resolve one's problems and to understand the meaning of life; one's sufferings get emphasized in online postings). The manifestations of the suicidal virtual personality are also influenced by parameters such as one's orientation (prosociality, asociality or anti-sociality), virtualization (time spent online; relationship between one's real and virtual images) and involvement (technical skills, identification with an online subculture).

The assessment of online behavior which is usually associated with pre-suicidal condition is rather controversial. It is mentioned that individuals in such condition spend more time online; create posts indicative of their emotional state and frequent the websites with suicidal content. It is shown that in this way the individuals actualize their need for support for understanding their emotions and seeing that their problems aren't unique (Marchant et al., 2017; Biddle et al., 2018). This is believed to be especially important to sensitive and withdrawn people (Durkee et al., 2011). There is also evidence that women are more inclined than men to look for support and to share online some of the aspects of their presuicidal condition (Sueki, 2015). They also seek constructive ways to handle stress. This is the positive aspect of the behavior described but it also involves negative effects, such as normalization and positive appraisal of suicidal behavior, seeking partners in suicide and unrestricted spreading of information on self-mutilating, and as well as increased levels of despair (Marchant et al., 2017).

Other research objects are long posts written by people in pre-suicidal condition. The posts were colored with depression, were self-focused, expressed negative emotions (psychological pain). The anonymity factor, conducive to more active sharing of one's ideas was observed, too (Barak and Miron, 2005). Sueki H. (2015) revealed the relations between suicide-related postings (including texts containing "want to commit suicide" and "want to die") and suicidal behavior. It turned out that the first wording (a more explicit one) is mostly related to a suicidal attempt and self-mutilation, whereas the second - with suicidal thoughts.

Certain cognitive distortions are peculiar to the adolescents possessing low sociometric status in their school groups and visiting certain online suicidal communities. It turned out that the predominant individual cognitive mechanisms were black-and-white thinking, catastrophization, personalization, devaluation of positive sides, emotional justification and labeling (Luchinkina A. I. and Luchinkina I. S., 2019).

In their study of risk factors of shaping suicidal behavior in children and adolescents, which was based on the analysis results of postmortem forensic psychological and psychiatric examination, 
Syrokvashina K. V. et al., (2019) point out that the majority of the adolescents who committed suicide were registered users of social networks. The authors believe that what really matters nowadays is not only the adolescent's online presence, but also the nature of his/her participation in various groups, the involvement in suicidal communities and discussing suicidal actions as something acceptable and tolerable. The study points out that posting suicidal content in one's personal pages isn't directly indicative of one's involvement in anti-life communities, but it can signify the actuality of the subject and the ideas for the adolescent and in some cases deliberation of a suicidal act.

General availability of the internet, dramatic development of online communications poses new challenges in the domain of psychological and interdisciplinary research. Not only does cyberspace make it easy for minors to communicate, but it also holds the potential risk of facing new forms of violence, abuse, sexual harassment and exploitation. Sexual grooming comes as a special form of online risktaking and victim behavior. Dozortseva E. G. and Medvedeva A. S. (2019) substantiate the relevance and necessity for diverse psychological study of grooming and describing the linguistic characteristics of this phenomenon, as well as the importance of research of children's vulnerability and resistance to this sort of sexual abuse, its consequences for children's mental development and also designing of preventive programs.

Due to their immaturity, minors aged 7-15 are vulnerable to different strategies of psychological impact used by individuals who perpetrate sexual crimes. Korchagin N.Yu. et al., (2020) also add to this category of manipulative techniques of psychological impact the following: "informing", "convincing", "instillation", "forcing".

Medvedeva A. S. and Dozortseva E. G. (2019) also mark out various characteristics in online grooming such as the sorts and stages of influence (e.g. contacting, preparation, sex-related communication), grooming tactics (e.g. provocative statements to evoke denial on the part of the minor and his/her subsequent emancipation, comparing him/her to the sexually emancipated peers in order to stimulate imitation; deception and misleading; threats; blackmailing; destructive criticism; insults etc.). It was shown that only $50 \%$ of minors in the sampling resisted online grooming, whereas the rest turned out to be susceptible to grooming tactics. In the authors' opinion, it may be indicative of their credulity, the minors' unawareness in the context of online risks and safety and in certain cases signify a tendency towards deviant behavior in the minors themselves. The interpretations given point to the need of developing preventive and educational programs for children and their parents.

\section{Models of risk assessment of deviant behavior}

Sarna A. Ya (2014) defines three major paradigms by highlighting certain objects of research (computer-mediated communications, the media and their representatives, the problems which users focus on etc):

1) The cultural and historical paradigm within which media content is considered as a logical stage of development in the history of mass communication media and computer technology; its multimedia, hypertextual and interactive nature is seen as the key features, technical features of means of communication on the Internet and capabilities of online communications etc (D. Bell, M. Castels, $L$. Manovich, A. Darley, H. Jenkins, B. Peters, V. Savchuk, N. Sokolova, D. Galkin, O. Goryunova et al.).

2) The social and psychological paradigm focuses on studying the specifics of users' selfpresentation and self-identification, on the gender and age of participants in online interaction, on the motives and details of their behavior and on either constructive or destructive effect the participants have on the socium etc (H. Bechar-Israeli, N. Ellison, R. Heino, J. Gibbs, D. Huffacker, B.G. Chenault, V. Nesterov, A. Myshenkova, E. Goroshko, A. Voiskunskiy et al.).

3) The linguistic paradigm focuses on studying the stylistic diffusion and the multilingual nature of the internet, the language changes occurring on the lexical, syntactical, grammatical and other levels, as well as the correlation between verbal and graphic communication components and discursive peculiarities in online communication practices etc (C. Thurlow, D. Crystal, J. Runkehl, P. Schlobinski, T. Siever, L. Ivanova, L. Shchipitsina, O. Dedova et al.).

The review of the studies shows that it's feasible to single out the following models for risk assessment of different kinds of deviant online behavior:

- respondents' subjective attitude to certain online phenomena and content they face on the internet and in social networks as users;

- media content found in various communities of social networks and online platforms whose users participate in those communities;

- media content found in users' personal profiles and pages; 
- users' psychological make-up on the basis of the data of psychological testing, including the tendency to offline deviant behavior and comparing these data with the users' activity in social networks.

In our view, the most productive approach to developing the model of risk assessment of deviant online behavior in adolescents is the cultural and historical one. In L. S. Vygotsky's cultural-historical concept it is maintained that mental growth is culturally conditioned and is transformed in the course of social and historical processes. In this theory there is an idea about the ontogenetic development as the relationship between the real (natural) and ideal (cultural) forms. The interaction between these forms gives orientation to development. Besides, it is the social environment, that determines and is the source of cultural development of a child, it also holds ideal forms (Vygotsky, 1983; Vygotsky, 1999; Kurysheva, 2003). Digital technology is a new instrument for mediation, whereas the online space is the virtual analog of how a society reproduces in real life (Rubtsova O. V., 2019). Consequently, the social situation of a child's development takes on a new form: not only does the child interact with his/her real social environment, but also with the reality and online virtuality combined together. Given that generally the social situation of development is a kind of a standard for relationships which comes as a result of the historical development of a society, in the real life of a child there can emerge an interpersonal situation of development reflecting that particular child's relationships with his/her immediate social environment in the reference groups he/she belongs to and on whose opinions he/she relies (Venger, 2014). At the same time, similarly to the real environment, the internet contains patterns and forms of both normative and non-normative behavior, and due to the aforementioned factors (anonymity, deindividuation etc.) the barriers to the latter are lowered in the online space. According to Vygotsky's concept, every mental function initially appears in the outer, social circle as interpsychic and, later on, as inner or intrapsychic. As a result of this interiorization process, the social beliefs, norms (or vice versa - anti-norms) of internet communities, reference groups are acquired by the child and come as his/her own beliefs, dispositions and behavioral regulators. The typical forms of the child's behavior become part of his/her individual and psychological features, which also regulate the behavior.

On the basis of the points given, a model is proposed for risk assessment of adolescents' deviant behavior. Such assessment must consider problem aspects, related to the risk of antisociality or victimhood, as well as the resources which address the adolescent person's needs and enabling his/her positive development. The following parameters are included in the assessment:

1. The values, norms and beliefs which are translated by the groups the adolescent person belongs to. The information analyzed are: the content of the websites and group chats, their participants' interests, mutual interactions and social beliefs.

2. The interindividual characteristics of adolescent's interactions with the virtual environment. The researched parameters are: the extent of one's online involvement (the risk of internet addiction, the breadth of his/her contacts), choice of contacts with internet communities (as represented in the adolescent's Web-based accounts), communication intensity, online self-presentation, linguistic peculiarities of one's expressions and conversations etc. It is important to notice the adolescent's current or past participation in hazardous activities on the internet (e.g. cyberbullying, joining suicidally inclined communities etc.). The adolescent's prosocial acts, interactions and self-presentation which are not peculiar to deviant behaviors are also taken into consideration.

3. The adolescent's intraindividual traits. It is important to find how the social norms of the online communities have effect on his/her individual consciousness, to which extent they are interiorized, how strongly they correlate with the adolescent's personal views, beliefs and attitudes. We also analyze individual psychological traits which are conducive to asocial manifestations (e.g. aggression, the traits belonging to the "dark triad" or "tetrad") or victimhood (personality's immaturity, anxiety, low self-esteem etc.), as well as individual traits which inhibit asocial or victim manifestations.

The information obtained as a result of such research will enable one to build an understanding of the adolescent's online activity and to probabilistically assess the risk of his/her online deviant behavior. It should be remembered though, that the social environment of the adolescent is an integral whole and his/ her virtual world should be considered in conjunction and interaction with his/her real one. Similarly, the traditional assessment of deviant behavior risk (based on the existing models) for today's adolescent would be incomplete without taking his/her online activities into account. It is the generalized comprehensive analysis that will make it possible to carry out an integral assessment of deviant behavior risk of the adolescent and, if necessary, develop a prevention/rehabilitation program.

It should also be noted that in the general context of the cultural-historical approach, the further elaboration of this problem will undoubtedly rely on the progress in psychosocial studies of social beliefs, situational norms, social identity, self-presentation and other phenomena which are important for understanding the structure and mechanisms of various group and interindividual processes in which 
adolescents are involved on the internet.

In comparison to the existing approaches for studying behavior of young internet users which implement partial theoretical ideas and concepts, the model we propose not only contains recognized theoretical grounds, but also encompasses different levels of analysis (group, interindividual, intraindividual). This model is a part of a more general system of risk assessment of deviant behavior in adolescents as a whole and is focused on practical application in social counseling of adolescents with deviant behavior and also in preventing such behavior. There are plans to methodically operationalize the model and develop appropriate research tools in the future.

\section{Conclusion}

In the contemporary era the internet technologies are becoming part of the worldview of people so much that they start feeling they are important participants in global processes. The internet and social media find their most active use in adolescent and youth circles.

Among the consequences of social media penetrating daily life, it seems possible to distinguish transformation and simplification of communication process, alteration of power relationships and communication standards. Participants in communication now have various options for keeping their anonymity (with the ensuing psychological consequences). They have freedom to a degree of enabling them to construct and modify their identities, interrupt and completely stop their communication at any moment

Misusing internet technologies results in a number of changes to the subject of communication himself/herself, among which are effort deficit, leading to voluntary regulation deficit. This, in turn, creates difficulties in initiating and planning one's activities, impairs control and brings about infantilization. Besides, higher mental functions isolation and irregularity in their hierarchical makeup is associated with "clipped mindset", barriers blurring, problems with undertaking obligations and responsibilities, subordination as well as diffused identity

The analysis of the studies indicates the negative side of using the internet and social networks, points to the emerging phenomena of the anti-normative spectrum. On the one hand, the explanatory line appeals to the deindividuation construct, which suggests that in this state a person behaves differently than outside it. The analysis of how one behaves in the internet space is hardly applicable to predicting one's actions in the real world.

On the other hand, there are reasons to suggest the existence of personality predictors of deviant behavior, transgression and violation of social norms. The configuration of these predictors includes the so-called dark tetrad (psychopathy, machiavellism, narcissism and sadism).

The analysis we performed makes it possible to outline a structured model for risk assessment based on the cultural-historical concept, which possesses a certain set of group, interindividual and intraindividual constructs. We think that this model of risk assessment is a promising way to predict how online and offline behavior correlate.

Besides, it should be possible to outline a direction to developing preventive measures against deviant behavior (both online and offline). This involves the construct of cognitive flexibility (we'll use one of the definitions dealing with mental ability that characterizes an "individual's ability to transform their cognitive attitudes in response to the changing conditions of their life activity" (Osavolyuk E.Yu., Kurginyan S.S. 2018, p.138). At the same time, psychological prevention aims to avert developmental and behavioral problems through creation of conditions for successful formation and development of the personality resources which would assist in coping with various difficult life situations and increasing resistance against adverse factors (Bogdanovich N. V. and Delibalt V. V., 2020). It is important to pay special attention to developing technologies of online and offline assistance for minors in response to the factors they face on the internet.

\section{Acknowledgements}

The authors are grateful to the administration of Moscow State University of Psychology and Education and personally to its chancellor Arkadiy A. Margolis for the support of the research project named "Development of a Model for Profiling Online Behavior of Minors and Young Adults in Social Networks", to Doctor of Engineering, professor, Dean of the Computer Science Faculty, Head of Chair of Applied Computer Science of Moscow State University of Psychology \& Education (MSUPE) Lev S. Kuravsky, Dr. Pavel N. Dumin, Tatyana A. Poskakalova, and also to the students and postgraduates of Department of Legal Psychology, MSUPE, who took part in this project: Alina A. Vukolova, Sofia M. Gureyeva, Nikita Yu. Korchagin, Yevgeniya D. Larina, Elena M. Startseva, Ekaterina V. Makovetskaya- 
Dvoryanchikov, V. N. et all. (2020). Deviant online behavior in adolescent and youth circles: in search of a risk assessment model, International Journal of Cognitive Research in Science, Engineering and Education (IJCRSEE), 8(2), 105-119

Serebryakova, Ekaterina. S. Ponomareva, Angelica A. Vakulenko, Nikita V. Lavreshkin, Daria V. Kiriukhina, Anastasia O. Kazina.

\section{Conflict of interests}

The authors have no conflict of interest.

\section{References}

Attrill, A. (2016). The Role of Culture in Online Behaviour. In Applied Cyberpsychology (pp. 39-57). Palgrave Macmillan, London. https://doi.org/10.1057/9781137517036 3

Aysina R. M., Nesterova A. A. (2019). Cyber socialization of youth in the information and communication space of the modern world: effects and risks. Sotsial'naia psikhologiia i obshchestvo [Social Psychology and Society], (10)4, 42-57. (In Russ., abstr. in Engl.). https://doi.org/10.17759/sps.2019100404

Bandura, A. (1977). Self-efficacy: Toward a unifying theory of behavioral change. Psychological Review, 84(2), $191-215$. https://doi.org/10.1037/0033-295X.84.2.191

Barak, A., \& Miron, O. (2005). Writing characteristics of suicidal people on the Internet: A psychological investigation of emerging social environments. Suicide and Life-Threatening Behavior, 35(5), 507-524. https://doi.org/10.1521/suli.2005.35.5.507

Biddle, L., Derges, J., Goldsmith, C., Donovan, J. L., \& Gunnell, D. (2018). Using the internet for suicide-related purposes: Contrasting findings from young people in the community and self-harm patients admitted to hospital. PLoS one, 13(5), e0197712. https://doi.org/10.1371/journal.pone.0197712

Bocij, P., \& McFarlane, L. (2003). Cyberstalking: The technology of hate. The Police Journal, 76(3), 204-221. https://doi. org/10.1350/pojo.76.3.204.19442

Bogdanovich, N. V., \& Delibalt, V. V. (2020). Prevention of Deviant Behavior of Children and Adolescents as a Field of Activity of a Psychologist in Educational Institutions. Psychology and Law, 10(2), 1-14. https://doi.org/10.17759/psylaw.2020100201

Bondarenko, S. V. (2004). The Social Make-up of Virtual Communities. Rostov-Don: Izdatel'stvo RGU = Rostov State University Publishing.

Brodovskaya, E. V., Dombrovskaya, A. Yu. \& Ivanov, I.S. (2016). Alteration in Online Behavior Strategies of Russian Internet Audience: Results of Comparative Cluster Analysis (2012-2014). Monitoring of Public Opinion: Economical and Social Changes, 3, 173-187. http://dx.doi.org/10.14515/monitoring.2016.3.10

Buckels, E. E., Trapnell, P. D. \& Paulhus, D. L. (2014). Trolls just want to have fun [Electronic version]. Personality and Individual Differences. Retrieved July 27, 2020, from: http://dx.doi.org/10.1016/j.paid.2014.01.016

Bulgakova, M. V., Dozortseva, E. G., Dreyzin, A. A., Oshevskiy, D. S., Polyatykin, S. A., Soldatova, T. E. (2009). A Guide on using the technique "Risks and opportunities assessment" (ROA) in counseling for juvenile offenders. Moscow: Russian Charitable Fund "Say No to Alcohol and Drugs".

Chitoşcă, M. I. (2006). The Internet as a socializing agent of the M Generation. Journal of Social Informatics, 5, 3-21. Retrieved from: http://citeseerx.ist.psu.edu/viewdoc/download?doi=10.1.1.101.4349\&rep=rep1\&type=pdf

Daine, K., Hawton, K., Singaravelu, V., Stewart, A., Simkin, S. \& Montgomery, P. (2013). The power of the web: a systematic review of studies of the influence of the internet on self-harm and suicide in young people. PloS one, 8(10), 1-6. http:// dx.doi.org/10.1371/journal.pone.0077555

Delaney, T., \& Madigan, T. (2017). Friendship and Happiness: And the Connection Between the Two. Jefferson, North Carolina, USA: McFarland \& Company, Inc., Publishers.

Delibalt, V. V., Degtyaryov, A. V., Dozortseva, E. G., Chirkina, R. V., Dvoryanchikov, N. V., \& Pimonov et al. (2017). Evaluation of cognitive functions, personality and regulatory sphere in minors with deviant and delinquent behavior within the authority of the psychological, medical and educational committee. International Journal of Cognitive Research in Science, Engineering and Education, 5(2), 107-118. http://dx.doi.org/10.5937//JCRSEE1702107D

Dolan, M., \& Doyle, M. (2000). Violence risk prediction: Clinical and actuarial measures and the role of the Psychopathy Checklist. The British Journal of Psychiatry, 177(4), 303-311. https://doi.org/10.1192/bjp.177.4.303

Dozortseva, E. G., \& Medvedeva, A. S. (2019). Sexual online grooming as an object of psychological research. Psychology and Law, 9(2), 250-263. http://dx.doi.org/10.17759/psylaw.2019090217

Dozortseva, E. G., Badmayeva, V. D., Oshevskiy, D. S. \& Alexandrova, N. A. (2011). The Assessment of Risk of Delinquent Acts in Children and Adolescents. A Guideline. Moscow: Federal State Budgetary Institution "V. Serbsky Federal Medical Research Centre for Psychiatry and Narcology" of the Ministry of Health of the Russian Federation.

Dozortseva, E. G., Oshevsky, D. S., \& Syrokvashina, K. V. (2020). Psychological, Social and Informational Aspects of Attacks by Minors on Educational Institutions. Psychology and Law, 10(2), 98. http://dx.doi.org/10.17759/psylaw.2020100208

Duggan, M. (2014). Online harassment. Pew Research Center. Retrieved from: https://www.pewresearch.org/ internet/2014/10/22/part-1-experiencing-online-harassment/

Durkee, T., Hadlaczky, G., Westerlund, M., \& Carli, V. (2011). Internet pathways in suicidality: a review of the evidence. International journal of environmental research and public health, 8(10), 3938-3952. http://dx.doi.org/10.3390/ ijerph8103938

Emelin, V. A., \& Tkhostov, A. (2015). Deformation of the chronotope in conditions of sociocultural acceleration. Voprosy filosofii, 2, 15-24.

Emelin, V. A., \& Tkhostov, A. (2013). The Babylonian network: the erosion of truth and the diffusion of identity in the Internet space. Voprosy filosofii, 1,74-84.

Emelin, V. A., \& Tkhostov, A. (2016). The temptations and pitfalls of temporal identity. Voprosy filosofii, 8, 115-125.

Festinger, L., Pepitone, A., \& Newcomb, T. M. (1963). Some Consequences of De-individuation in a Group. In N. J. Smelser \& W. T. Smelser (Eds.), Personality and social systems (p. 125-135). John Wiley \& Sons Inc. https://doi.org/10.1037/11302012

www.ijcrsee.com 
Dvoryanchikov, V. N. et all. (2020). Deviant online behavior in adolescent and youth circles: in search of a risk assessment model, International Journal of Cognitive Research in Science, Engineering and Education (IJCRSEE), 8(2), 105-119

Global digital report 2019 - We are social. Retrieved from: https://wearesocial.com/global-digital-report-2019

Helsper, E. J. (2014). Offline social identity and online chat partner selection. Information, Communication \& Society, 17(6), 695-715. https://doi.org/10.1080/1369118X.2013.810767

Hinduja, S., \& Patchin, J. W. (2014). Bullying beyond the schoolyard: Preventing and responding to cyberbullying. Corwin Press.

Hoge, R. D., \& Andrews, D. A. (2002). The youth level of service/case management inventory manual and scoring key. Toronto, Canada: Multi-Health Systems.

Hoge, R. D. , \& Andrews, D. A. , \& Leschied, A. W. (2002). The Youth Level of Service/Case Management Inventory. Toronto, Canada: Multi-Health Systems.

Internet in Russia: the dynamics of invasion. Winter 2017-2018 [Electronic version]. Retrieved July 27, 2020, from: https:// fom.ru/SMl-i-internet/13999

Java, A., Song, X., Finin, T., \& Tseng, B. (2007, August). Why we twitter: understanding microblogging usage and communities. In Proceedings of the $9^{\text {th }}$ WebKDD and 1st SNA-KDD 2007 workshop on Web mining and social network analysis (pp. 56-65). https://doi.org/10.1145/1348549.1348556

John, A., Glendenning, A. C., Marchant, A., Montgomery, P., Stewart, A., Wood, S., ... \& Hawton, K. (2018). Self-harm, suicidal behaviours, and cyberbullying in children and young people: Systematic review. Journal of medical internet research, 20(4), e129. https://doi.org/10.2196/jmir.9044

Joinson, A. N. (2007). Causes and implications of disinhibited behavior on the Internet. In: J. Gackenbach (ed.). Psychology and the Internet. Boston, MA: Academic Press, pp. 43-60.

Keith, S., \& Martin, M. E. (2005). Cyber-Bullying: creating a culture. Reclaiming children and youth, The Journal of Strength-based Interventions, 134(3), 224-228. Retrieved from: https://intranet.newriver.edu/images/stories/library/ stennett_psychology_articles/Cyber-Bullying $\% 20-\% 20$ Creating $\% 20 \mathrm{a} \% 20 \mathrm{Culture} \% 20$ of $\% 20$ Respect $\% 20 \mathrm{in} \% 20 \mathrm{a} \% 20$ Cyber\%20World.pdf

Kende, A., Ujhelyi, A., Joinson, A. \& Greitemeyer, T. (2015). Putting the social (psychology) into social media. European Journal of Social Psychology, 45, 277-278. https://doi.org/10.1002/ejsp.2097

Khlomov, K. D., Davydov, D. G., \& Bochaver, A. A. (2019). Cyberbullying in the Experience of Russian Teenagers. Psychology and Law, 9(2), 276-295. https://doi.org/10.17759/psylaw.2019090219

Kiryukhina, D. V. (2019). Кибербуллинг среди молодых пользователей социальных сетей [Сyberbullying among young users of social networks]. Современная зарубежная психология, 8(3), 53-59. https://doi.org/10.17759/jmfp.2019080306

Korchagin, N. Y., Dvoryanchikov, N. V., Antonov, O. Y., \& Shulga, T. I. (2020). Specifics of Psychological Impact Strategies for Persons Committing Sexual Crimes Against Minors through the Internet. Psychology and Law, 10(2), 111-126. https:// doi.org/10.17759/psylaw.2020100209

Kowalski, R. M., Limber, S. P., \& Agatston, P. W. (2012). Cyberbullying: Bullying in the digital age. John Wiley \& Sons.

Kurysheva, O. V. (2003). The Idea of Relationship between Real and Ideal Forms in the Tradition of Cultural and Historical Development Theory. Vestnik Volgogradskogo Gosudarstvennogo Universiteta = Herald of Volgograd State University, Series 7: Philosophy. Sociology and social technologies, 3(3), 131-137.

Lebon, G. (2011). Psychology of peoples and masses. Moscow: Academic project.

Livingstone, S., Haddon, L., Görzing, A. \& Ölafsson, K. (2011). EU kids online II: final report 2011. EU Kids Online. London: London School of Economic and Political Science.

Lowry, P. B., Zhang, J., Wang, C., \& Siponen, M. (2016). Why do adults engage in cyberbullying on social media? An integration of online disinhibition and deindividuation effects with the social structure and social learning model. Information Systems Research, 27(4), 962-986. https://doi.org/10.1287/isre.2016.0671

Luchinkina, A.I. \& Luchinkina, I.S. (2019). The Specifics of Communicational Behavior in Cyberspace in Adolescents with Various Types of Suicidal Behavior. Rossiyskiy psikhologicheskiy zhurnal/Psychology in Russia, 16(1), 128-143. https://doi.org/10.21702/rpj.2019.1.6

Luchinkina, A.I. (2015). Model of Online Socializing of Personality. Informational and psychological personal security in cyberspace, Simferopol, 6-13.

Madle, G., Berger, A., Cognat, S., Menna, S., \& Kostkova, P. (2009). User information seeking behaviour: Perceptions and reality. An evaluation of the WHO Labresources Internet portal. Informatics for Health and Social Care, 34(1), 30-38. https://doi.org/10.1080/17538150902779204

Makushkin E. V., Dozortseva E. G., Badmayeva V. D., Oshevskiy D. S. (2009) Clinical and psychological methods for risk assessment of aggressive acts by minors: an analytical review. // Federal State Budgetary Institution "V. Serbsky Federal Medical Research Centre for Psychiatry and Narcology" of the Ministry of Health of the Russian Federation, Moscow, Russia, P. 1-29.

Marchant, A., Hawton, K., Stewart, A., Montgomery, P., Singaravelu, V., Lloyd, K., ... \& John, A. (2017). A systematic review of the relationship between internet use, self-harm and suicidal behaviour in young people: The good, the bad and the unknown. PloS one, 12(8), e0181722. https://doi.org/10.1371/journal.pone.0181722

Martínez-Ferrer, B., Moreno, D., \& Musitu, G. (2018). Are adolescents engaged in the problematic use of social networking sites more involved in peer aggression and victimization?. Frontiers in psychology, 9, 801. https://doi.org/10.3389/ fpsyg.2018.00801

Marzouki, Y. (2016). La conscience collective virtuelle: un nouveau paradigme des comportements collectifs en ligne. Les représentations sociales. Théories, méthodes et applications. Louvain-la-Neuve: De Boeck Supérieur, 413-415.

McMurran, M. (1996). Substance use and delinquency. Clinical approaches to working with young offenders, 1, 209-235.

Mededovic, J. \& Petrovic, B. (2015). The Dark tetrad. Journal of Individual Differences, 36(4), 228-236. https://doi. org/10.1027/1614-0001/a000179

Medvedeva, A. S., \& Dozortseva, E. G. (2019). Features of online grooming as a form of sexual exploitation of minors (based on the analysis of communication between adults and children in the Internet). Psychology and Law, 9(4), 161-173. https://doi.org/10.17759/psylaw.2019090412

Monahan, J., \& Steadman, H. J. (Eds.). (1996). Violence and mental disorder: Developments in risk assessment. University of Chicago Press. 
Moor, L., \&Anderson, J. R. (2019). A systematic literature review of the relationship between dark personality traits and antisocial online behaviours. Personality and individual differences, 144, 40-55. https://doi.org/10.1016/j.paid.2019.02.027

Moreno, M. A., Ton, A., Selkie, E., \& Evans, Y. (2016). Secret society 123: Understanding the language of self-harm on Instagram. Journal of Adolescent Health, 58(1), 78-84. https://doi.org/10.1016/j.jadohealth.2015.09.015

Muller, R. D., Skues, J. L., \& Wise, L. Z. (2017). Cyberbullying in Australian primary schools: How victims differ in attachment, locus of control, self-esteem, and coping styles compared to non-victims. Journal of psychologists and counsellors in schools, 27(1), 85-104. https://doi.org/10.1017/jgc.2016.5

Osavolyuk, E.Yu., Kurginyan, S.S. (2018) Cognitive Flexibility of Personality: Theory, Measurement, Practice. Psychology, 15(1), 128-144. https://doi.org/10.17323/1813-8918-2018-1-128-144

Owens, L., Shute, R., \& Slee, P. (2000). I'm in and you're out: Explanations for teenage girls indirect aggression. Psychology, Evolution \& Gender, 2(1), 19-46. https://doi.org/10.1080/14616660050082906

Panicheva, P., Ledovaya, Y., \& Bogolyubova, O. (2016, November). Lexical, morphological and semantic correlates of the dark triad personality traits in Russian Facebook texts. In 2016 IEEE artificial intelligence and natural language conference (AINL) (pp. 1-8). IEEE. Retrieved July 27, 2020, from: https://ieeexplore.ieee.org/abstract/document/7891860

Pelaprat, E., \& Brown, B. (2012). Reciprocity: Understanding online social relations. First Monday, 17(10). https://doi. org/10.5210/fm.v17i10.3324

Pellegrini, A. D., \& Bartini, M. (2001). Dominance in early adolescent boys: Affiliative and aggressive dimensions and possible functions. Merrill-Palmer Quarterly, 47(1), 142-163. Retrieved from: https://www.jstor.org/stable/23093691

Pleshakov, V.A. (2012). Cyber Socializing of Humans: From Homo Sapiens to Homo Cyberus Moscow: Prometey.

Polskaya, N. A., \& Yakubovskaya, D. K. (2019). The Impact of Social Media Platforms on Self-Injurious Behavior in Adolescents. Counseling Psychology and Psychotherapy, 27(3), 171. Retrieved from: https://psyjournals.ru/files/108483/cpp_2019_ n3.pdf\#page $=172$

Pronk, R. E., \& Zimmer-Gembeck, M. J. (2010). It's "Mean," But What Does It Mean to Adolescents? Relational Aggression Described by Victims, Aggressors, and Their Peers. Journal of Adolescent Research, 25(2), 175-204. https://doi. org/10.1177/0743558409350504

Rubtsova, O. V., Panfilova, A. S., \& Smirnova, V. K. (2018). Research on Relationship between Personality Traits and Online Behaviour in Adolescents (With VKontakte Social Media as an Example). Psychological Science and Education, 3, 54-66. https://doi.org/10.17759/pse.2018230112

Rubtsova, O. V. (2019). Digital Media as a New Means of Mediation (Part One). Cultural-Historical Psychology, 15(3), 117-124. https://doi.org/10.17759/chp.2019150312

Rutter, M. (1985). Resilience in the face of adversity: Protective factors and resistance to psychiatric disorder. The British journal of psychiatry, 147(6), 598-611. https://doi.org/10.1192/bjp.147.6.598

Sanders, J., Smith, P. K., \& Cillessen, A. (2009, August). Cyberbullies: Their motives, characteristics, and types of bullying. In fourteenth European Conference on Developmental Psychology, Vilnius, Lithuania.

Sarna, A. Ya.(2014). Content Analysis in Studying the New Media. Vestnik Volgogradskogo Gosudarstvennogo Universiteta/ Herald of Volgograd State University, Series 7: Philosophy. Sociology and Social Technologies, 23(3), 88-98.

Schumann, S., \& Klein, O. (2015). Substitute or stepping stone? Assessing the impact of low-threshold online collective actions on offline participation. European Journal of Social Psychology, 45(3), 308-322. https://doi.org/10.1002/ejsp.2084

Semenov, A., Veijalainen, J., \& Kyppo, J. (2010). Analysing the presence of school-shooting related communities at social media sites. International Journal of Multimedia Intelligence and Security, 1(3), 232-268. https://doi.org/10.1504/ IJMIS.2010.037540

Short, C., Rebar, A., Plotnikoff, R., \& Vandelanotte, C. (2015). Designing engaging online behaviour change interventions: a proposed model of user engagement. The European Health Psychologist, 17(1), 32-38. Retrieved from: https://digital. library.adelaide.edu.au/dspace/bitstream/2440/97646/3/hdl_97646.pdf

Smahel, D., MacHackova, H., Mascheroni, G., Dedkova, L., Staksrud, E., Olafsson, K., ... \& Hasebrink, U. (2020). EU Kids Online 2020: Survey results from 19 countries. https://doi.org/10.21953/lse.47fdeqj01ofo

Sokolova, M. V., \& Dozortseva, E. G. (2019). The Tendency to Auto-aggressive Behavior in Adolescents and the Information they consume on the Internet. Psychology and Law, 9(1), 22-35. https://doi.org/10.17759/psylaw.2019090102

Soldatova, G. U. (2018). Digital socialization in the cultural-historical paradigm: a changing child in a changing world. Social Psychology and Society, 9(3), 71-80. https://doi.org/10.17759/sps.2018090308

Soldatova, G. U., Nestik, T. A., Rasskazova, E. I., \& Zotova, E. J. (2013). Cifrovaja kompetentnost'podrostkov i roditelej. Rezul'taty vserossijskogo issledovanija [Digital competence in adolescents and parents. The results of the national study]. Moscow: Internet Development Foundation.

Soldatova, G.U., Chigarkova, S.V. \& Lvova, E.N. (2017). Online Aggression and Adolescents: the Results of Studying Schoolchildren in the City of Moscow and Moscow Region. Epokha Nauki/The Science Epoch, 12, 103-109.

Spears, B., Slee, P., Owens, L., \& Johnson, B. (2009). Behind the scenes and screens: Insights into the human dimension of covert and cyberbullying. Zeitschrift für Psychologie/Journal of Psychology, 217(4), 189-196. https://doi. org/10.1027/0044-3409.217.4.189

Sueki, H. (2015). The association of suicide-related Twitter use with suicidal behaviour: a cross-sectional study of young internet users in Japan. Journal of affective disorders, 170, 155-160. https://doi.org/10.1016/j.jad.2014.08.047

Suler, J. (2004). The online disinhibition effect. Cyberpsychology \& behavior, 7(3), 321-326. https://doi. org/10.1089/1094931041291295

Syrokvashina, K. V., Oshevsky, D. S., Badmaeva, V. D., Dozortseva, E. G., Makushkin, E. V., Aleksandrova, N. A., ... \& Shkityr, E. Y. (2019). Risk factors of fashioning of suicidal behavior in children and adolescents (based on the analysis of regional posthumous forensic evaluation). Psychology and Law, 9(1), 71-84. https://doi.org/10.17759/psylaw.2019090105

Tikhonova, A. D., Dvoryanchikov, N. V., Ernst-Vintila, A., \& Bovina, I. B. (2017). Radicalisation of Adolescents and Youth: In Search of Explanations. Cultural-Historical Psychology, 13(3), 32-40. https://doi.org/10.17759/chp.2017130305

Tkhostov, A. Sh. (2018). Transformation of higher mental functions in the era of the information society [Electronic version]. Retrieved July 27, 2020, from: https://www.youtube.com/watch?v=B8FuleaAWfo

Vaske, E. V. \& Goryunova, O. I. (2018) Psychological and Legal Analysis of Destructive Manifestations on the Internet. Vestnik 

model, International Journal of Cognitive Research in Science, Engineering and Education (IJCRSEE), 8(2), 105-119

Nizhegorodskogo Universiteta I'm N.I. Lobachevskogo/Herald of Lobachevsky N. I. University of Nizhniy Novgorod, 6, 104-110.

Venger, A. L. (2014). Psychological Syndromes: Approaches to the Design of Content Diagnostics of Development. Культурно историческая психология/Cultural-Historical Psychology. 10(1), 20-25. Retrieved from: https://psyjournals.ru/ files/67569/kip 2014 1.pdf\#page=25

Vygotsky, L. S. (1983). The History of Development of the Higher Mental Functions. Collected works. Moscow. Vol. 3.

Vygotsky, L. S. (1999). The Problems of the Psychology of the Child. Saint Petersburg.

Wallinius, M. (2012). Aggressive antisocial behavior- clinical, cognitive, and behavioral covariates of its persistence. Department of Clinical Sciences, Lund University. Retrieved from: https://portal.research.lu.se/portal/en/publications/ aggressive-antisocial-behavior-clinical-cognitive-and-behavioral-covariates-of-its-persistence(3e1f693b-2c9c-436e8ce6-59a76126d5ea)/publications.html

Wenar C. \& Kerig, P. (2007). Developmental psychopathology. Saint Petersburg, AST Holding, Prime-EvroZnak Publishing. $1-672$.

Whitty, M. T., Doodson, J., Creese, S., \& Hodges, D. (2018). A picture tells a thousand words: What Facebook and Twitter images convey about our personality. Personality and Individual Differences, 133, 109-114. https://doi.org/10.1016/j. paid.2016.12.050

Ybarra, M. L., \& Mitchell, K. J. (2004). Online aggressor/targets, aggressors, and targets: A comparison of associated youth characteristics. Journal of child Psychology and Psychiatry, 45(7), 1308-1316. https://doi.org/10.1111/j.14697610.2004.00328.x

Young, K. S. (1998). Internet addiction: The emergence of a new clinical disorder. Cyberpsychology \& behavior, 1(3), $237-244$. http://dx.doi.org/10.1089/cpb.1998.1.237

Zhdanova, S.Y. \& Doronina, V.F. (2019). Controlling content-related risks which students have in social networks. Herald of the Perm State Pedagogical Institute, Series 1, Psychological and Pedagogical Science, 1, 36-43.

Zmanovskaya, E. V. (2003). Deviantology (Psychology of Deviant Behavior). Moscow: Academy Publishing Centre, 1-288. 